\title{
Effects of Mud from a Zinc-plating Plant and Zeolite Saturated with Zinc on Portland Cement Hydration and Properties of Hardened Cement Pastes
}

\author{
D. Barbir," P. Dabić, and A. Lisica \\ University of Split, Faculty of Chemistry and Technology, \\ Department of Inorganic Technology, Ruđera Boškovića 35, \\ 21000 Split, Croatia
}

doi: $10.15255 / \mathrm{CABEQ} .2016 .846$

Original scientific paper

Received: February 26, 2016

Accepted: November 30, 2016

This work investigates the impact of mud from a zinc-plating plant and zeolite saturated with zinc on early hydration processes of ordinary Portland cement. During the first 48 hours of hydration, the addition of mud significantly affects the cement hydration kinetics. The partial replacement of cement with zeolite saturated with zinc ions, reduces the negative impact of mud on the hydration processes. Samples with the additions showed lower compressive strength than the sample without additions. With regard to the standard limits for this type of cement, mud shares are eligible up to $5 \mathrm{wt}$. \% and a mixture of mud and saturated zeolite up to $10 \mathrm{wt}$. \%.

Keywords:

ordinary Portland cement, mud from a zinc-plating plant, waste zeolite, TG/DTG, compressive strength

\section{Introduction}

Metal electroplating industries generate large amounts of waste materials that contain heavy metals. These materials cannot be applied for commercial purposes and must be properly disposed. The most commonly binder for the disposal of heavy metal wastes is Portland cement. ${ }^{1-4}$

The reactions of Portland cement and waste materials can be very complex. ${ }^{5-8}$ In general, most of the crystalline calcium silicate from cement reacts with water to form an amorphous hydrated calcium silicate (Tobermorite gel) and crystalline calcium hydroxide (Portlandite). Tobermorite gel is the main binding component of the stabilized waste, while Portlandite creates an alkaline environment ( $\mathrm{pH}>12) .{ }^{9}$ The hydroxide converts heavy metal ions from waste into their poorly soluble hydroxides. Portlandite is partially soluble and over an extended period under the influence of moisture diffuses through the pores, and leaches from the solidified waste. Therefore, its leaching can lead to degradation of the structure of solidified material. ${ }^{10}$ Hydration of cement can be changed under the influence of heavy metals. ${ }^{11}$ Poon et al. concluded that the metals contained in the sparingly soluble hydroxides slow down hydration, while those consisting of soluble hydroxides accelerate hydration processes. ${ }^{12,13}$ Retarder is attributed to the reduction of permeability of the resulting products, which

"Corresponding author: Damir Barbir; Tel: +38521 329 460;

Fax: +38521 329 461; Email: dbarbir@ktf-split.hr leads to the deposition of undissolved metal gel on the surface of cement particles. ${ }^{14}$ The reaction rates of cement phase do not depend only on the composition and structure, but also on the temperature, size, particle shape as well as the presence of added accelerators and retarders (gypsum, calcium chloride, calcium hydroxide, $\mathrm{CO}_{2}$ ).

In an alkaline environment as present during cement hydration, the surface of cement particles are negatively charged. Although neutral or less positive surface can adsorb metal cations, though most metal cation adsorbed negatively charged surface of the particle. ${ }^{15-17}$ Most available cations in solution are $\mathrm{Ca}^{2+}$, and it is believed that the coated surface of the silicate creating a highly charged Ca-layer. Metal anions in solution will compete for adsorption sites, creating an additional layer. Asavapisit et al. examined this competition for adsorption of studying the effects of synthetic zinc hydroxide on $\mathrm{Ca}^{2+}$ ions during the hydration of ordinary Portland cement. ${ }^{18}$ They concluded that during the early hydration of Alite, dissolves large quantities of zinc. They assumed that these ions prevent the formation of $\mathrm{Ca}(\mathrm{OH})_{2}$ in the first week of Alite hydration. Poon and colleagues through porosity and leaching experiments showed that $\mathrm{Zn}$ is stabilized in cement matrix. Observed leaching was not in accordance with the measured porosity of the matrix, and concluded that the chemical stabilization is more important than the physical metal retention in the structure. ${ }^{12}$

Replacement supplements include substances that are not good for stabilization of waste, but in 
combination with cement can be successfully applied for stabilization of wastes. Use of these supplements lies primarily in two basic reasons. The first reason is the achievement of certain changes in cement composites for plastic or solid state composites. Another reason is economical, where expensive cement clinker is replaced with a less expensive material. This supplement has to be integrated into complex processes of hydration. ${ }^{19}$

Using of zeolite lot of promises in the stabilization of waste, due to its low cost and able to implement such alternative technologies as compared to expensive chemical and physical removal of contamination. Zeolites are crystalline hydrated aluminosilicates of alkali and alkaline earth elements. Natural zeolites are available in nature and can be used as "crude" material. In addition, they are resistant to the erosion. Lately, natural and modified zeolites have become very popular because of the ability to bind heavy metals and radioactive substances. Application of natural zeolites in the treatment of wastewater contaminated with toxic metals (zinc, iron, chromium etc.) is very large because of the economic viability, excellent physical and chemical properties of zeolites and a very important aspect, environmental acceptability. The structure of zeolite consists of a three-dimensional network $\left(\mathrm{SiO}_{4}\right)^{4-}$ and $\left(\mathrm{AlO}_{4}\right)^{5-}$ tetrahedra, connected by oxygen. Neutralization of the negative charge at $\left(\mathrm{AlO}_{4}\right)^{5-}$ tetrahedra is performed by installing hydrated alkali and alkaline earth metal cations $\left(\mathrm{Na}^{+}, \mathrm{K}^{+}, \mathrm{Ca}^{2+}\right.$, $\mathrm{Mg}^{2+}$ ) entering the cavities and channels which show very high mobility. The structure of the zeolite is different from the other and the other crystalline aluminosilicate materials in the presence of structural voids interconnected channels of a particular size and shape. The nature of free space in dehydrated zeolites is important in determining the physical and chemical properties. A number of studies on the use of natural zeolites as supplementary materials have been published in recent years. ${ }^{20-22}$ Poon et al. studied the rate of hydration of cement pastes blended with natural zeolite. ${ }^{23}$ Zeolite is added in an amount of $25 \mathrm{wt} . \%$ and blended cement samples had almost the same compressive strength as well as cement samples without addition after 28 days of hydration. Krolo et al. studied conduction calorimetry by using zeolite with 40 to $50 \%$ of clinoptilolite with other impurities like illite, clay, feldspar etc. They showed that hydration of the blended samples was enhanced by the presence of zeolite for the first 15 hours of hydration. With the addition of zeolite up to $50 \mathrm{wt}$. \% total heat released was higher than that of control cement sample and the main peak of heat release rate is shifted towards earlier times of hydration. ${ }^{24}$ Perakki et al. replaced a cement with natural zeolite by up to $30 \mathrm{wt}$. \%. They examined the content of $\mathrm{Ca}(\mathrm{OH})_{2}$ in hydrated cement - zeolite pastes by thermogravimetric analysis. The content of $\mathrm{Ca}(\mathrm{OH})_{2}$ was lower than in control cement paste indicating the pozzolanic reaction of zeolite. ${ }^{25}$ Uzal et al. examined the compressive strength of cement samples with addition of zeolite up to $50 \mathrm{wt}$. \%. They concluded that early compressive strength was lower than that of the control cement paste. However, it became higher after 28 days of hydration. ${ }^{26}$

In the present study, a mud from a zinc-plating plant and natural zeolite saturated with zinc as supplementary material were added to ordinary Portland cement in different proportions. The primary objective of this research was: determine the acceptable share of mud and the saturated zeolite in the matrix of the new cement composite. This work studied effects of these additions on early hydration processes by determining the heat of hydration and specific electrical conductivity of cement pastes. The Portlandite and chemically bound water content of hydrated cement paste was evaluated by thermogravimetric analysis (TG/DTG). Compressive strength was also tested.

\section{Materials and methods}

\section{Materials and sample preparation}

For all examined samples an ordinary Portland cement OPC type CEM I $42.5 \mathrm{R}$ was used. OPC was obtained from CEMEX Croatia cement plant from Kaštel Sućurac, Croatia. It shows high early and final strength with a short period of beginning of setting and optimum workability. Its average chemical composition and physical properties are shown in Table $1 .^{27}$

As a supplementary material to cement was used natural zeolite (Donje Jesenje site, Krapina, Croatia) saturated with zinc ions. Saturation is carried out with a solution containing $9.0 \mathrm{mmol} \mathrm{dm}{ }^{-3}$ $\mathrm{ZnSO}_{4}$. Zeolite contains the main mineral clinoptilolite and impurities as illite, feldspar and quartz (Figure 1). ${ }^{24}$ The chemical composition of the natural zeolite are shown in Table 1. Saturated zeolite has simulated waste which gets after wastewater treatment in zinc-plating plant.

Mud from a zinc-plating plant ADRIACINK Split, Croatia, was produced by precipitation of zinc plant wastewater with lime and filtration of the precipitate. The mud was approximately $80 \mathrm{wt}$ \% solids. The composition of mud obtained by AAS spectroscopy after acid decomposition was $\left(\mathrm{mg} \mathrm{L}^{-1}\right)$ : $\mathrm{Zn} \mathrm{157.30,} \mathrm{Fe} 392.70$ and $\mathrm{Ca}$ 67.10. The saturated zeolite and mud were dried at $105{ }^{\circ} \mathrm{C}$ to constant weight, ground and sieved through a $90 \mu \mathrm{m}$ sieve. 


\begin{tabular}{|c|c|c|c|c|}
\hline $\begin{array}{c}\text { Chem. } \\
\text { compo- } \\
\text { sition, } \\
\text { (wt. \%) }\end{array}$ & $\mathrm{OPC}$ & $\begin{array}{l}\text { Natural } \\
\text { zeolite }\end{array}$ & $\begin{array}{c}\text { Physical properties } \\
\text { of OPC }\end{array}$ & Value \\
\hline $\mathrm{SiO}_{2}$ & 22.85 & 64.93 & $\begin{array}{l}\text { Specific surface according } \\
\text { to Blaine }\left(\mathrm{cm}^{2} \mathrm{~g}^{-1}\right)\end{array}$ & 3300 \\
\hline $\mathrm{Al}_{2} \mathrm{O}_{3}$ & 4.81 & 13.66 & Standard consistency $(\%)$ & 26 \\
\hline $\mathrm{Fe}_{2} \mathrm{O}_{3}$ & 2.79 & 2.03 & Setting time - start $(\min )$ & 85 \\
\hline $\mathrm{CaO}$ & 65.23 & 2.99 & Setting time - end (min) & 150 \\
\hline $\mathrm{MgO}$ & 1.61 & 1.10 & $\begin{array}{l}\text { Average flexural strength } \\
(\mathrm{MPa})\end{array}$ & \\
\hline $\mathrm{K}_{2} \mathrm{O}$ & 1.89 & 1.88 & after 2 days & 4.14 \\
\hline $\mathrm{Na}_{2} \mathrm{O}$ & 0.18 & 3.66 & after 28 days & 5.61 \\
\hline \multirow[t]{2}{*}{$\begin{array}{l}\text { Loss of } \\
\text { ignition }\end{array}$} & 0.04 & 9.75 & $\begin{array}{l}\text { Average compressive } \\
\text { strength (MPa) }\end{array}$ & \\
\hline & & & after 2 days & 27.42 \\
\hline Total & 99.40 & 100.00 & after 28 days & 51.27 \\
\hline
\end{tabular}

Table 2 - Preparation of sample for microcalorimetric measurement

\begin{tabular}{c|c|c|c}
\hline Sample & OPC, g & Mud, g & $\begin{array}{c}\text { Saturated } \\
\text { zeolite, } g\end{array}$ \\
\hline 1 & 3.92 & 0.08 & 0.00 \\
2 & 3.80 & 0.20 & 0.00 \\
3 & 3.60 & 0.40 & 0.00 \\
4 & 3.60 & 0.08 & 0.32 \\
5 & 3.20 & 0.16 & 0.64 \\
6 & 2.80 & 0.24 & 0.96 \\
\hline
\end{tabular}

The mud has a $\mathrm{pH}$ of 6.58 , the percentage of soluble part of the mud in distilled water was $17.85 \%$. Loss of ignition at $1000{ }^{\circ} \mathrm{C}$ was $20.70 \%$.

Cement samples for microcalorimetric measurement were prepared by mixing OPC and 2, 5 and 10 wt. \% of mud (Sample 1, 2 and 3) for first batch and mixing OPC with 10, 20 and 30 wt. \% of mixture mud + saturated zeolite with 20 wt. \% of mud in the mixture (Sample 4, 5 and 6) for the second batch (Table 2). A water to solid ratio of 0.5 was used for all mixes and measurements were carried out at a temperature of $20{ }^{\circ} \mathrm{C}$. The total mass of the solid sample was constant and it was $4 \mathrm{~g}$.

Preparation of samples for conductivity measurement were the same as for the microcalorimetric measurement. The total mass of the solid sample was constant and it was $100 \mathrm{~g}$. Sample was the cylinder height $4 \mathrm{~cm}$ and $3 \mathrm{~cm}$ in diameter.

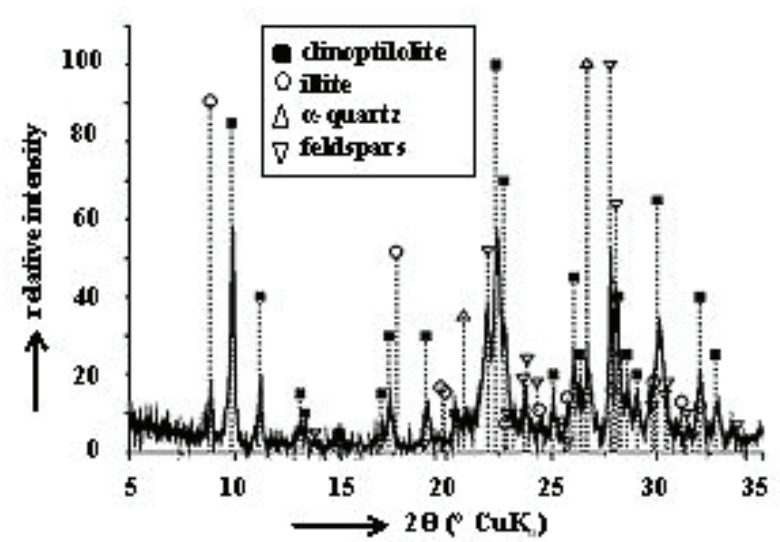

Fig. 1 - The XRD patterns of natural zeolite samples - deposit of Donje Jesenje, Krapina, Croatia

Cement pastes for TG/DTG analysis were hydrated 28 days at a constant temperature of $20{ }^{\circ} \mathrm{C}$. After curing time samples were crushed, ground and sieved through a $90 \mu \mathrm{m}$ sieve.

Cement mortars for determination of compressive strength were prepared according to the standard EN 196-1. The ratio of aggregate and binder (cement + mud + mixture of mud and saturated zeolite) was constant and it was $3: 1$. Standardized quartz sand was used, and the water-cement and the water / solid ratio was constant and was 0.5 for all samples. Prepared samples are placed in a mold dimensions $160 \times 40 \times 40 \mathrm{~mm}$ and kept the first 24 hours in a climate chamber at a temperature of 20 ${ }^{\circ} \mathrm{C}$. After that, samples were cured in thermostatted pool with temperature water $T=20 \pm 1{ }^{\circ} \mathrm{C}$.

\section{Methods}

Chemical composition of cement and zeolite was determined by an EDXRF Twin-X device, Oxford Instruments.

The effects of admixtures on hydration processes was determined by differential microcalorimeter of the conduction-isoperibolic type. An ALMEMO 2390-8 data logger, Ahlborn, Germany, was used to trace changes of voltage $\mathrm{d} U=\mathrm{f}(t)$ due to changes of temperature in the samples during the hydration process. The measured values of thermovoltage are than processed on a computer program and calculated values of total heat released, the heat release rate and relative reaction degree for the first 48 hours of hydration. ${ }^{28}$

The specific electrical conductivity is determined by Iskra MA 5964 microprocessor conductometer, Slovenia, connected to a computer via a RS 232 C digital output. The conductivity cell electrodes were made of stainless steel with a constant $C=0.285 \mathrm{~cm}^{-1}$. The electrodes were polished before the experiment. Samples were placed in the 
space between the electrodes and the cell was kept at a temperature of $20^{\circ} \mathrm{C}$. The measurement begins 3 minutes after first contact of sample with water.

Thermal analysis were performed on a Pyris 1 TGA, Perkin Elmer, USA, at $20{ }^{\circ} \mathrm{C} \mathrm{min}-1$ from 50 to $850{ }^{\circ} \mathrm{C}$ in $10 \mathrm{~mL} \mathrm{~min}{ }^{-1} \mathrm{~N}_{2}$ flow.

After 2 , and 28 days of curing at $100 \%$ relative humidity, the compressive strength was measured according to EN 196-1 standard with a Toni Technik press, Germany.

\section{Results and discussion}

From the thermovoltage values measured, rate of heat release, total heat of hydration and the relative degree of hydration were calculated for Portland cement samples with different additions of mud and mixture of mud and zeolite. The results are shown in Figures 2, 3 and 4.

During hydration occurring effects that are manifested in the form of maximum and minimum at different hydration times. The first peak is short in duration and occurs immediately upon contact of water and cement composites. In this initial period take place reactions of wetting, dissolution and hydrolysis. Immediately upon contact of cement with water, ion-exchange appearances between the solid and liquid phases.

Formation of first hydration products develop a large amount of heat. The shape, size and position of the main peak depends on the amount of supplements in the cement composites. In the cement sample without the additions registered a very strong main peak, that with the increase of mud and mixture of mud and saturated zeolite becomes less pronounced. By increasing of supplements maximums become smaller, and occurrence of peak is moved towards later times of hydration. After a maximum period of deceleration followed by hydration which is characterized by a small amount of heat developed and reduced overall rate of hydration.

The results show that the addition of mud and mixture of mud and zeolite directly affects the final value of the heat of hydration. Increasing of content of mud from 2 to $10 \mathrm{wt}$. \% and a mixture of saturated zeolite and mud from 10-30 wt. \% leads to decreasing of final value of the heat of hydration in the first 48 hours of hydration. Sample 1 develops heat of hydration of $175.4056 \mathrm{~J} \mathrm{~g}^{-1}$, while Sample 3 develops $101.3725 \mathrm{~J} \mathrm{~g}^{-1}$. The addition of zeolite in the system cement-mud reduces the negative impact of mud on the developed heat of hydration (Sample 4-171.4998 $\mathrm{J} \mathrm{g}^{-1}$ and Sample 6-127.9755 $\mathrm{J} \mathrm{g}^{-1}$ ). The value of the heat of hydration of the control sample (Portland cement without the addition) is 188.2810 $\mathrm{J} \mathrm{g}^{-1}$. As can be seen, addition of a mud more reduc-
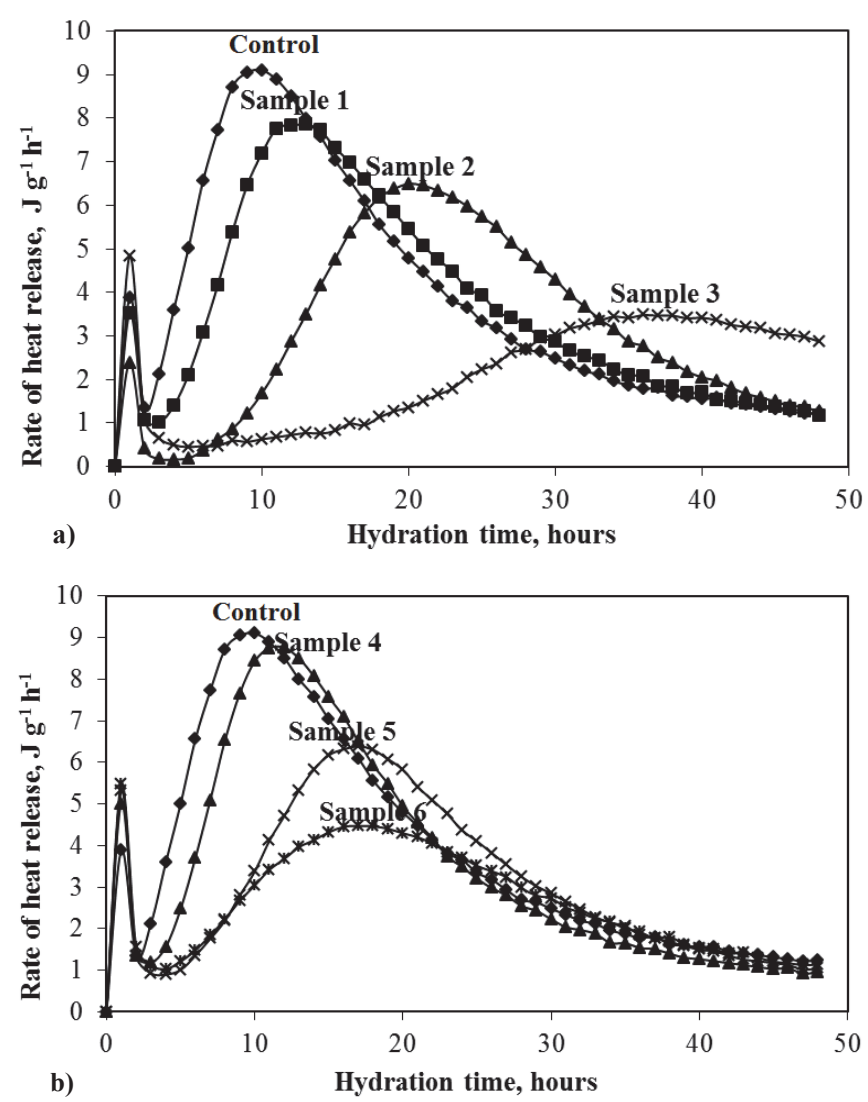

Fig. 2 - Heat release rate for samples with addition of mud (a) and mixture of saturated zeolite + mud (b)
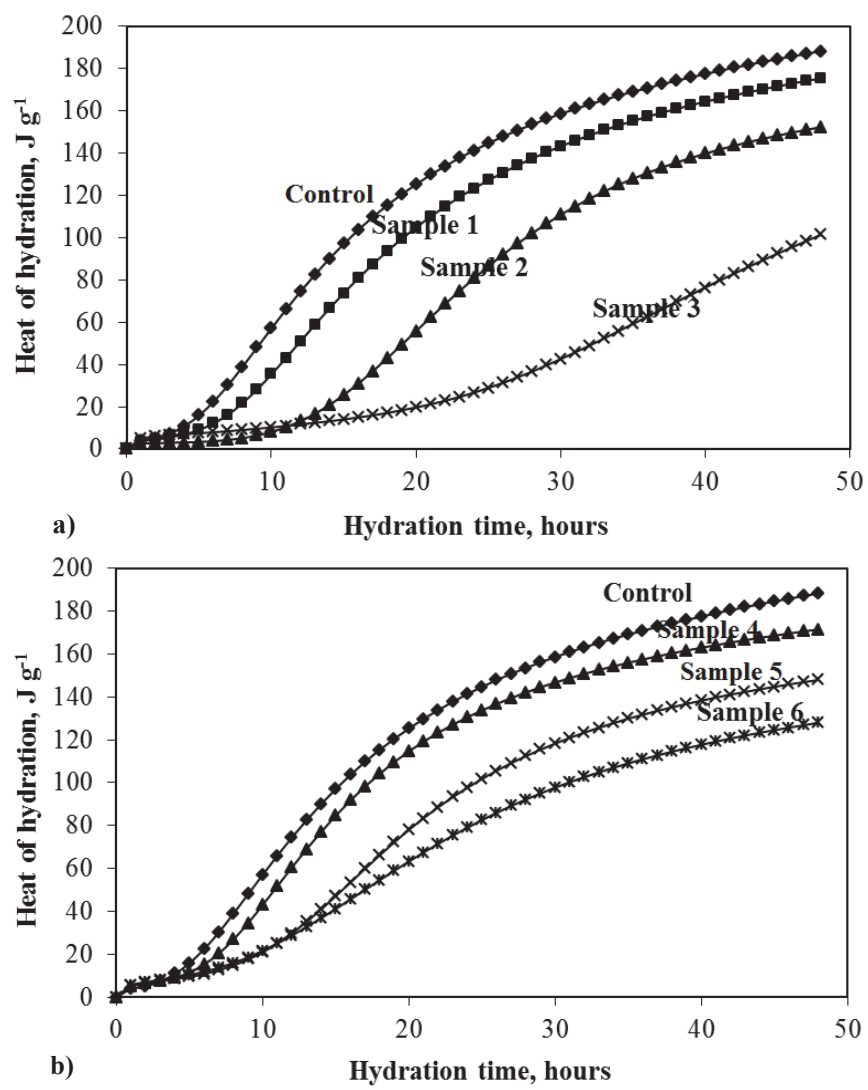

Fig. 3 - Heat of hydration dependence of hydration time for different additions of mud from a zinc plating plant (a) and mixture of waste zeolite + mud (b) 

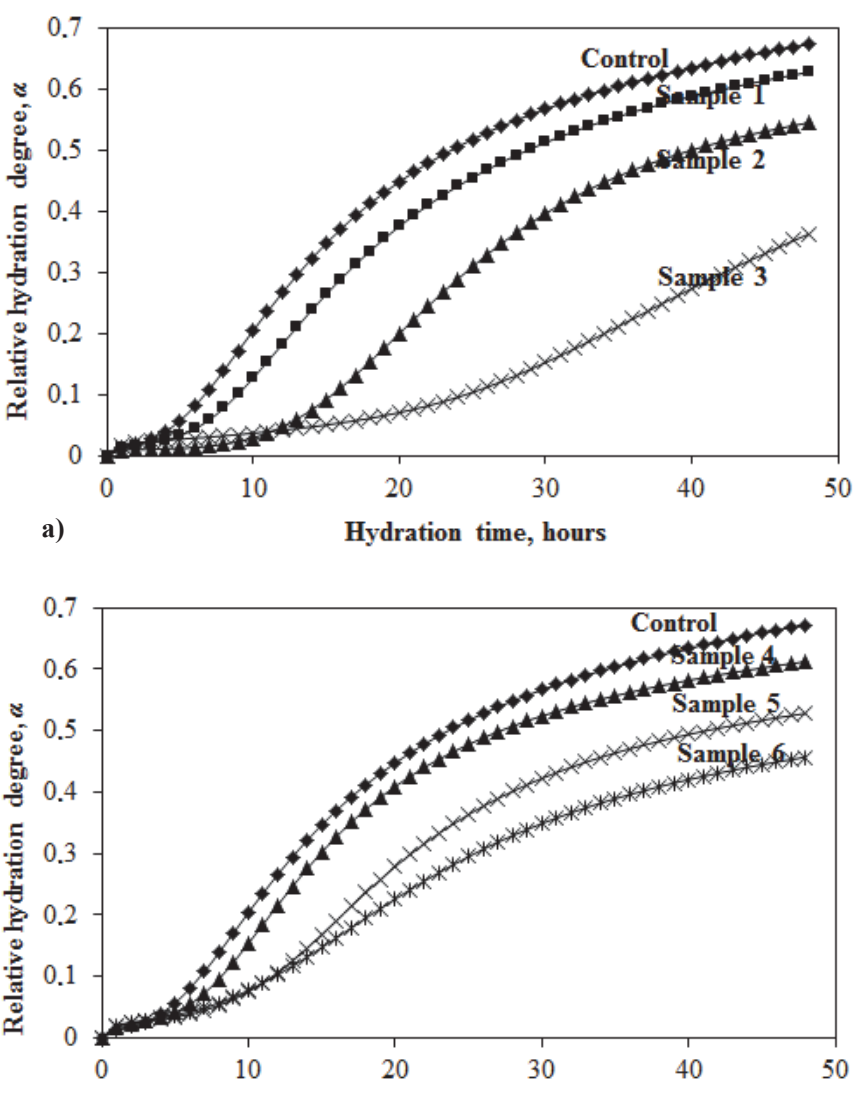

b)

Hydration time, hours

Fig. 4 - Relative degree of hydration for samples with addition of mud (a) and mixture of saturated zeolite + mud (b)

es the heat of hydration than the addition of mixture of mud and zeolite.

At relative degree of hydration curves notices the similarity with heat of hydration curves. Analysis of results shows that the relative degree of hydration depends about the content of addition in cement sample. It is evident that the addition of mud runs towards lower values of relative degree of hydration. Sample 1 has relative degree of hydration 0.63 , while Sample 3 has 0.36 . The addition of zeolite in the system cement-mud reduces the negative impact of mud on the relative degree of hydration (Sample 4-0.61 and Sample 6-0.46).

Measurements of specific electrical conductivity allow monitoring of hydration process, structural changes and setting time of cement pastes and mortars. Electrical conductivity occurs under the influence of the motion of ions. When cement reacts with water, it liberates $\mathrm{Ca}(\mathrm{OH})_{2}$ during the hydration process and leads to the complete decomposition of the alkali sulfate to $\mathrm{K}^{+}, \mathrm{Na}^{+}$and $\mathrm{SO}_{4}{ }^{2-}$ ions. Conductometric maximum value depends on the number and mobility of the ions. The newly formed hydration products coated cement particles, leading to the formation of the insulating layer which pre- vents the movement of ions and reduces throughput. Consequently, the transformation of the monosulfate and Ettringite increase the osmotic pressure around the cement particles, which leads to cracking of the coating and the acceleration of hydration..$^{29,30}$ This peak corresponds to the initial setting time of cement paste. Dependence of specific electrical conductivity on the hydration time of cement samples with the addition of the mud and mixture of mud and zeolite is shown in Figure 5.

Figure 5a shows the appearance of the conductivity maximum in the period of 95-550 minutes. Increasing the content of mud shifts the peak to later times of hydration and maximum conductivity values are lower. The results indicate that the addition of mud slows down the cement hydration processes. These results are in agreement with the results of determining the heat of hydration. Zeolite addition up to $30 \mathrm{wt}$. \% in cement-mud system reduces the negative impact of mud on the hydration process (Figure 5b). Maximum conductivity is achieved within a time period of 180-245 minutes. These results are in agreement with the microcalorimetric results.

Thermogravimetric analysis was used for determination of content of Portlandite $\left(\mathrm{Ca}(\mathrm{OH})_{2}\right)$ and chemically bound water. Based on the changes in mass of the sample in the temperature range 400 $550{ }^{\circ} \mathrm{C}$, it is possible to determine the content of Portlandite. Portlandite is the only product of hydration, with the exact chemical composition through which it is possible to monitor the hydration processes. Thermal decomposition of $\mathrm{Ca}(\mathrm{OH})_{2}$ can be represented by the chemical reaction:

$$
\mathrm{Ca}(\mathrm{OH})_{2(\mathrm{~s})} \rightarrow \mathrm{CaO}_{(\mathrm{s})}+\mathrm{H}_{2} \mathrm{O}_{(\mathrm{g})}
$$

The weight loss from the reaction (1) corresponding to the loss of chemically bound water in this temperature range. From this loss, content of Portlandite can be determine according to equation 2:

$$
w\left(\mathrm{Ca}(\mathrm{OH})_{2}\right)=\frac{\Delta m_{400-550^{\circ} \mathrm{C}} \cdot M\left(\mathrm{Ca}(\mathrm{OH})_{2}\right.}{M\left(\mathrm{H}_{2} \mathrm{O}\right)}
$$

where $w\left(\mathrm{Ca}(\mathrm{OH})_{2}\right)$ is content of Portlandite (wt. \%), $\Delta m_{400-550{ }^{\circ} \mathrm{C}}$ weight loss during the dehydration of calcium hydroxide, $M\left(\mathrm{Ca}(\mathrm{OH})_{2}\right)$ molar weight of calcium hydroxide and $M\left(\mathrm{H}_{2} \mathrm{O}\right)$ molar weight of water.

Content of chemically bound water (CBW) is determined by the hydrated samples in the temperature range from 50 to $850^{\circ} \mathrm{C}$ according to equation 3 :

$w(\mathrm{CBW})=\frac{\Delta m_{50-850^{\circ} \mathrm{C}}-\Delta m_{50-105^{\circ} \mathrm{C}}-\Delta m_{400-550^{\circ} \mathrm{C}}-\Delta m_{650-800^{\circ} \mathrm{C}}}{m_{\text {sample }}}$

where $\Delta m_{50-850^{\circ} \mathrm{C}}$ is weight loss in temperature range from $50-850{ }^{\circ} \mathrm{C}, \Delta m_{50-105{ }^{\circ} \mathrm{C}}$ weight loss in tempe- 


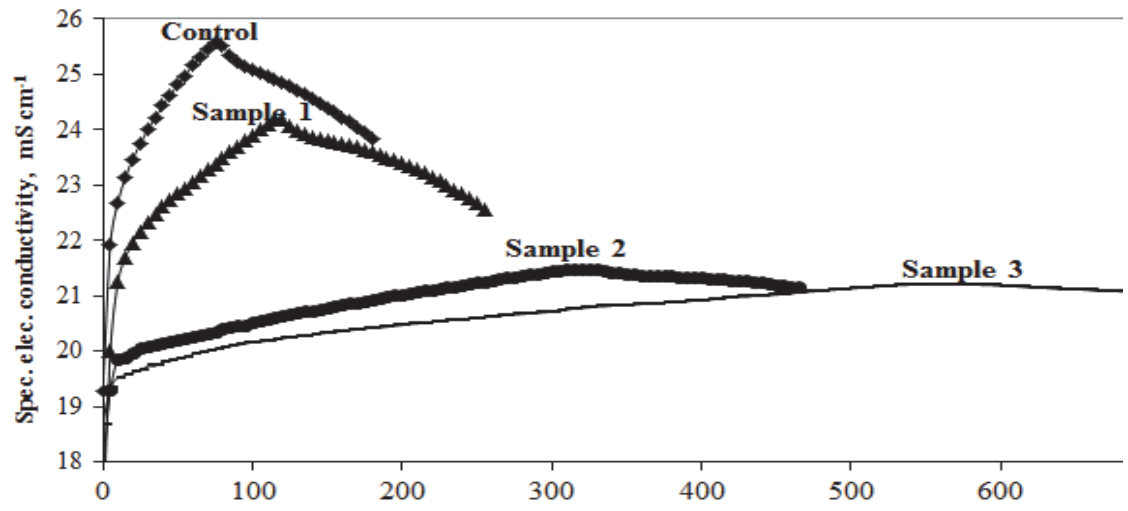

a)

Hydration time, minutes

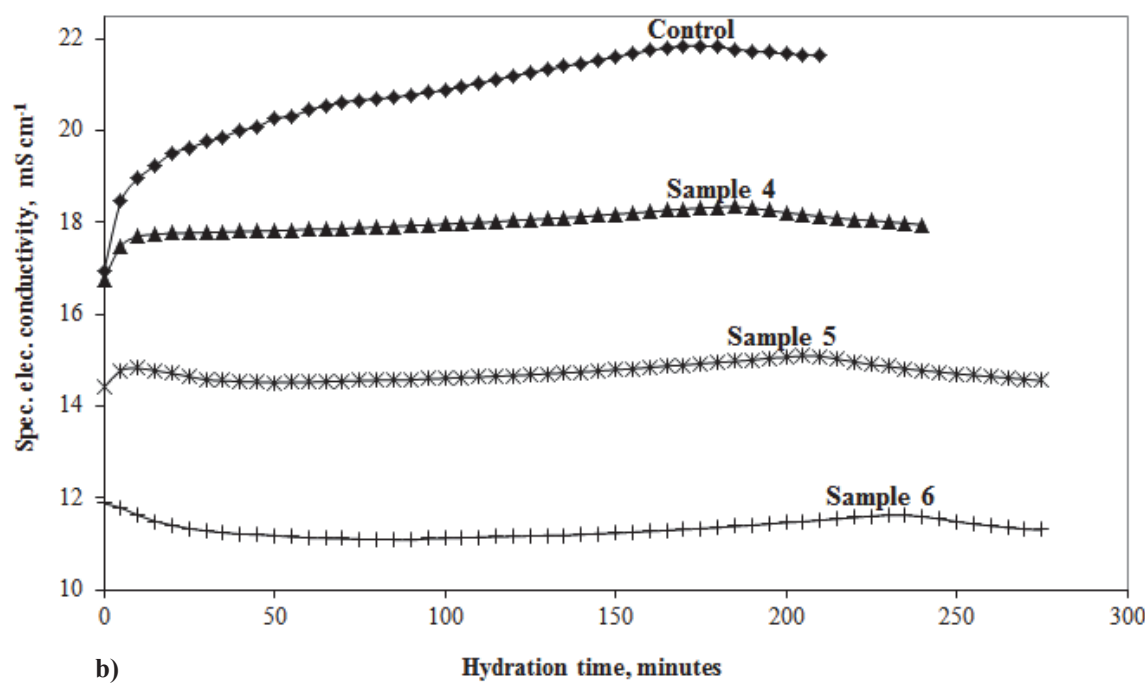

Fig. 5 - Specific electrical conductivity for samples with addition of mud (a) and mixture of saturated zeolite+mud (b)

rature range from $50-105^{\circ} \mathrm{C}, \Delta m_{400-550^{\circ} \mathrm{C}}$ weight loss in temperature range from $400-550{ }^{\circ} \mathrm{C}, \Delta m_{650-800^{\circ} \mathrm{C}}$ weight loss in temperature range from $650-800^{\circ} \mathrm{C}$ and $m$ sample mass of cement sample.

Results of the thermogravimetric analysis are shown in Table 3 and Figures 6 and 7.
The results indicate that with addition of mud to Portland cement, the content of calcium hydroxide decreases, while CBW content increases. This indicates that there is a reaction between the resulting calcium hydroxide with zinc and other constituents from the mud.

Table 3 - Thermogravimetric data for hydrated cement sample with addition of mud and mixture of mud and zeolite

\begin{tabular}{l|c|c|c|c|c|c|c}
\hline \multicolumn{1}{c|}{ Experimental data } & \multicolumn{3}{c}{ Calculated values } \\
\hline Sample & $\Delta T_{\mathrm{CH}} /{ }^{\circ} \mathrm{C}$ & $\Delta m_{50-105}, \mathrm{mg}$ & $\Delta m_{\mathrm{CH}}, \mathrm{mg}$ & $\Delta m_{\mathrm{CC}}, \mathrm{mg}$ & $\Delta m_{50-850}, \mathrm{mg}$ & $\mathrm{CH}$, wt. \% & $\begin{array}{c}\text { Chem. bound. } \\
\mathrm{H}_{2} \mathrm{O}, \text { wt. \% }\end{array}$ \\
\hline Sample 1 & $400-550$ & 0.16 & 0.92 & 0.25 & 2.65 & 25.31 & 9.26 \\
Sample 2 & $400-550$ & 0.19 & 0.88 & 0.38 & 2.76 & 23.03 & 9.22 \\
Sample 3 & $410-550$ & 0.22 & 0.93 & 0.51 & 3.41 & 20.07 & 11.33 \\
Sample 4 & $415-550$ & 0.19 & 0.69 & 0.32 & 2.27 & 21.24 & 9.87 \\
Sample 5 & $409-550$ & 0.15 & 0.57 & 0.26 & 2.08 & 16.79 & 12.13 \\
Sample 6 & $405-530$ & 0.28 & 0.86 & 0.79 & 3.97 & 13.03 & 14.57 \\
\hline
\end{tabular}




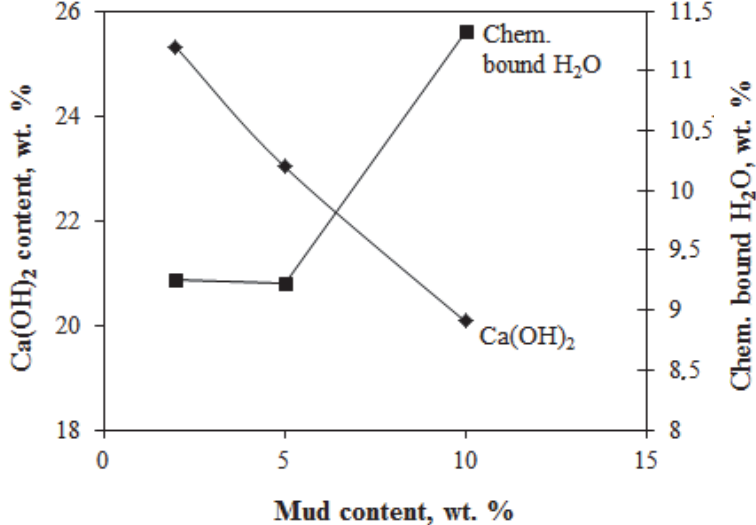

Fig. 6 - Content of Portlandite and $C B W$ in hydrated samples with addition of mud from a zinc-plating plant

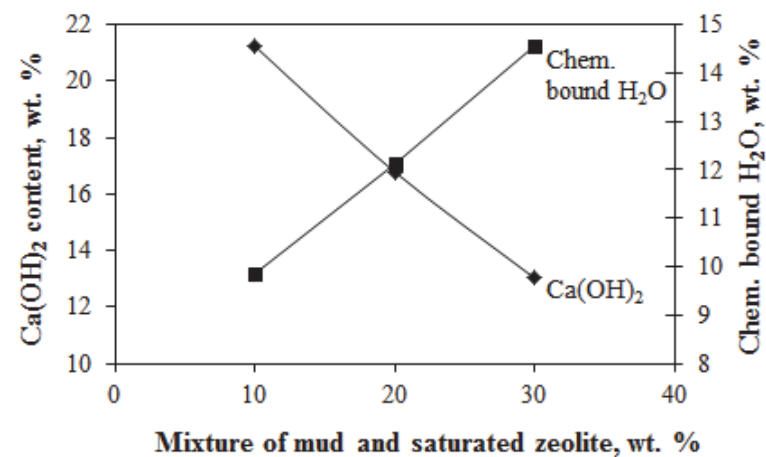

Fig. 7 - Content of Portlandite and $C B W$ in hydrated samples with addition of mixture of saturated zeolite+mud

With addition of a mixture of saturated zeolite and mud to cement, the content of calcium hydroxide decreases more, while the content of CBW is increasing rapidly than with addition of the mud. Pozzolanic reaction between the active ingredients from zeolite and calcium hydroxide leads to decrease of calcium hydroxide content with increasing content of CBW. ${ }^{21,31,32}$ Figures 8 and 9 showed calcium hydroxide content and initial setting time in dependence to the addition of mud and the mixture of mud and saturated zeolite.

The compressive strength development of mortars without addition and cement mortars with addition of mud and mixture of mud and waste zeolite is shown in Figure 10. According to standard EN 1971 , early strength for OPC should be $\geq 20 \mathrm{MPa}$ (after two days of hydration), and normalized strength after 28 days of hydration should be $\geq 42.5 \mathrm{MPa}$.

Results of measuring strength of mortars with addition of 2, 5, and $10 \mathrm{wt}$. \% of mud indicate lower values of compressive strength compared to the reference sample without addition. With regard to the standard limit, additions up to $5 \mathrm{wt}$. \% of mud satisfy these conditions. The addition of a mixture of mud and waste zeolite in the amount of 10,20

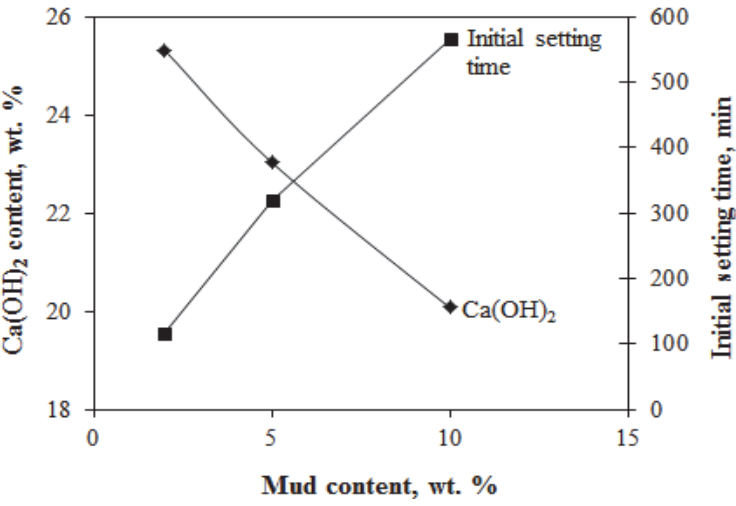

Fig. 8 - Content of Portlandite and initial setting time in samples with addition of mud

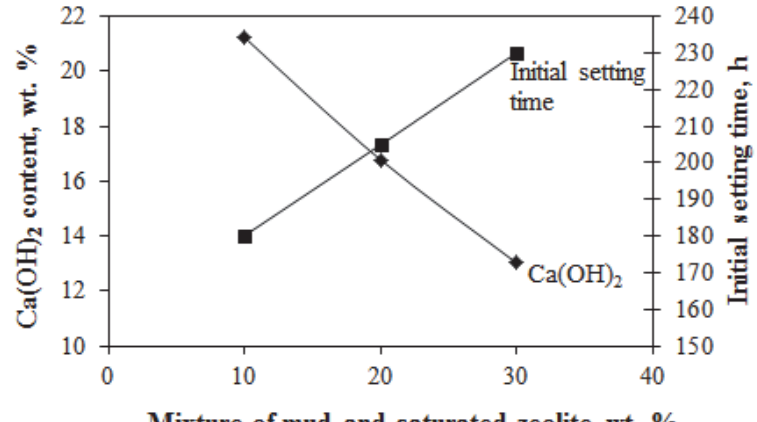

Fig. 9 - Content of Portlandite and initial setting time in samples with addition of mixture of saturated zeolite+mud

and 30 wt. \% leads to an even greater reduction in compressive strength compared to the reference sample. Standard limit satisfies only a sample containing $10 \mathrm{wt} . \%$ of mixture. In spite of the fact that the addition of zeolite reduces the negative effect of the mud on the hydration reactions, in case of compressive strengths zeolite shows the counter effect.

Table 4 - Mathematical models for calculation of the compressive strength of the samples with the addition of mud and mixture of saturated zeolite and mud

\begin{tabular}{l|c|c}
\hline \multicolumn{1}{c|}{ Sample } & $\begin{array}{c}\text { Mathematical model for } \\
\text { compressive strength }\end{array}$ & $\begin{array}{c}\text { Correlation } \\
\text { index }\end{array}$ \\
\hline Control & $c=11.243 \ln (t)+13.776$ & 0.94 \\
Sample 1 & $c=10.336 \ln (t)+13.258$ & 0.93 \\
Sample 2 & $c=10.030 \ln (t)+15.069$ & 0.93 \\
Sample 3 & $c=7.789 \ln (t)+15.216$ & 0.97 \\
Sample 4 & $c=10.811 \ln (t)+10.521$ & 0.97 \\
Sample 5 & $c=8.083 \ln (t)+8.2403$ & 0.93 \\
Sample 6 & $c=8.857 \ln (t)+4.7176$ & 0.99 \\
\hline
\end{tabular}




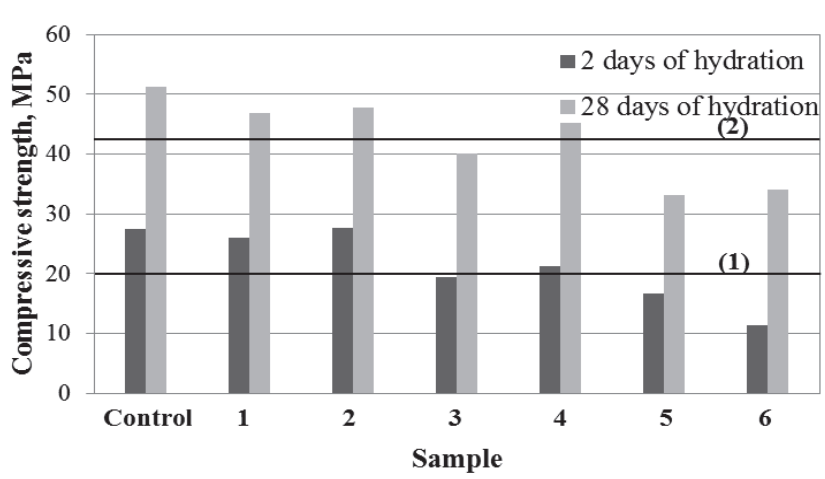

(1) standard compressive strength limit after 2 days of hydration (2) standard compressive strength limit after 28 days of hydration

Fig. 10 - Compressive strength development for samples with addition of mud and mixture of saturated zeolite +mud

From the results of determining the compressive strength, it is possible to calculate the compressive strength at any time of hydration of the tested supplements. Mathematical models are shown in Table 4.

Example of calculation of compressive strength after 10 days of hydration of the sample with the addition of 2 wt. $\%$ of mud:

$$
\begin{aligned}
& t=\text { hydration time after } 10 \text { days of hydration, } \\
& c=10.336 \ln (t)+13.258 \\
& c=10.336 \ln (10)+13.258 \\
& c=37.06 \mathrm{MPa}
\end{aligned}
$$

where $c$ is compressive strength in $\mathrm{MPa}$ and $t$ is time of hydration in days.

\section{Conclussions}

Based on the measurements and the obtained results it can be concluded:

- Microcalorimetric and conductimetric method enables continuous monitoring and determining the impact of various additives on the kinetic processes of hydration during early hydration.

- During the first 48 hours of hydration, increasing the amount of mud leads to the decline of heat of hydration, while the heat release rate maximums are shifted to later times of hydration. The partial replacement of cement with zeolite saturated with zinc ions, reduces the negative impact of supplements on the heat of hydration.

- Increasing the content of mud in cement composite slows down setting of composites, and the maximum of spec conductivity acquires lower values and move towards later times of hydration. Partial replacement of cement with zeolite reduces the negative effect of supplements on setting time.

- Thermogravimetric analysis shows that the addition of mud lead to reduction in the content of
$\mathrm{Ca}(\mathrm{OH})_{2}$. The content of CBW increases with additions as indicated on the creation of new hydration products. Partial replacement of cement with waste zeolite due to pozzolanic reaction occurs less quantity of Portlandite with a concurrent increase in the contents of CBW.

- From the results of compressive strength of mortars with different additions of mud and mixture of waste zeolite and mud it can be concluded that the samples with the additions showed lower compressive strength than the sample without additions. With regard to the standard limits for this type of cement, mud shares are eligible to $5 \mathrm{wt} . \%$ and a mixture of waste zeolite and mud to $10 \mathrm{wt}$. \%.

- Mathematical models are determined by which it is possible to calculate the compressive strength at any time of hydration for the questioned system.

\section{ACKNOWLEDGEMENTS}

The authors wish to express their gratitude to the Ministry of Science, Education and Sport of the Republic of Croatia, which has been financing a project, a part of which is presented in this report.

\section{List of symbols}

TG/DTG - thermogravimetric analysis

OPC - ordinary Portland cement

CBW - chemically bound water

\section{References}

1. Svensson, B. M., Mårtensson, L., Mathiasson, L., Eskilsson, $L$. , Leachability testing of metallic wastes, Waste Manag. and. Res. 23 (2005) 457.

doi: https://doi.org/10.1177/0734242X05058684

2. Chen, Q., Zhang, L., Ke, Y., Hills, C. D., Kang, Y., Influence of carbonation on the acid neutralization capacity of cements and cement-solidified/stabilized electroplating sludge, Chemosphere 74 (2009) 758.

doi: https://doi.org/10.1016/j.chemosphere.2008.10.044

3. Hills, C. D., Pollard, S. J. T., The influence of interference effects on the mechanical, microstructural and fixation characteristics of cement-solidified hazardous waste forms, J. Hazard. Mater. 52 (1997) 171.

doi: https://doi.org/10.1016/S0304-3894(96)01806-7

4. Barbir, D., Dabić, P., Krolo, P., Hydration study of ordinary Portland cement in the presence of lead(II) oxide, Chem. Biochem. Eng. Q. 27 (2013) 95.

5. Pang, X., Bentz, D. P., Meyer, C., Funkhouser, G. P., Darbe, $R$., A comparison study of Portland cement hydration kinetics as measured by chemical shrinkage and isothermal calorimetry, Cem. Concr. Comp. 39 (2013) 23.

doi: https://doi.org/10.1016/j.cemconcomp.2013.03.007

6. Taylor, H. F. W., Cement Chemistry, Thomas Telford Press, 1997, pp 1-28.

doi: https://doi.org/10.1680/cc.25929.0001 
7. Đureković, A., Cement, cementni kompozit i dodaci za beton, IGH and Školska knjiga, 1996, pp 20-55.

8. Vance, K., Aguayo, M., Oey, T., Sant, G., Neithalath, N., Hydration and strength development in ternary Portland cement blends containing limestone and fly ash or metakaolin, Cem. Concr. Comp. 39 (2013) 93. doi: https://doi.org/10.1016/j.cemconcomp.2013.03.028

9. Odler, I., Hydration, Setting and Hardened of Portland Cement, in Hewlett, P. C. (Ed.), Lea's Chemistry of Cement and Concrete, Elsevier Science and Technology Books, Oxford, 2004, pp 241-298.

10. Shi, $C$., Hydraulic Cement Systems for Stabilization/solidification, in Spence, R. D., Shi, C. (Eds.), Stabilization and Solidification of Hazardous, Radioactive, and Mixed Wastes. CRC Press, Boca Raton, 2005, pp 49-78.

11. Cannell, B. S., Eghmy, T. T., Krzow, J. E., Heavy metal stabilisation in municipal solid waste combustion bottom ash using soluble phosphate, Waste Manag. 20 (2000) 135. doi: https://doi.org/10.1016/S0956-053X(99)00312-8

12. Poon, C. S., Clark, A. I., Peters, C. J., Perry, R., Mechanisms of metal fixation and leaching by cement based fixation processes, Waste Manag. Res. 3 (1985) 127. doi: https://doi.org/10.1177/0734242X8500300114

13. Poon, C. S., Clark, A. I., Perry, R., Permeability study of the cement based solidification process for the disposal of hazardous wastes, Cem. Concr. Res. 16 (1986) 161 doi: https://doi.org/10.1016/0008-8846(86)90132-8

14. Santanu, P., Pak, K., Yuet, N., Solidification/stabilization of organic and inorganic contaminants using Portland cement: a literature review, Environ. Reviews 14 (2006) 217. doi: https://doi.org/10.1139/a06-004

15. Cheng, K. Y., Bishop, P. L., Sorption, important in stabilised/solidified waste forms, Hazard. Waste Hazard. Mater. 9 (1992) 289. doi: https://doi.org/10.1089/hwm.1992.9.289

16. Tamas, F. D., Electrical conductivity of cement pastes, Cem. Concr. Res. 12 (1992) 115. doi: https://doi.org/10.1016/0008-8846(82)90106-5

17. Kitamura, M., Konno, H., Yasui, A., Masuoka, H., Controlling factors and mechanism of reactive crystallisation of calcium carbonate polymorphs from calcium hydroxide suspensions, J. Crystal Growth 236 (2002) 323. doi: https://doi.org/10.1016/S0022-0248(01)02082-6

18. Asavapisit, S., Fowler, G., Cheeseman, C. R., Solution chemistry during cement hydration in the presence of metal hydroxide wastes, Cem. Concr. Res. 27 (1997) 1249. doi: https://doi.org/10.1016/S0008-8846(97)00109-9

19. Feng, P., Miao, C., Bullard, J. W., A model of phase stability, microstructure and properties during leaching of Portland cement binders, Cem. Concr. Composites 49 (2014) 9. doi: https://doi.org/10.1016/j.cemconcomp.2014.01.006
20. Napia, C., Sinsiri, T., Jaturapitakkul, C., Chindaprasirt, P., Leaching of heavy metals from solidified waste using Portland cement and zeolite as a binder, Waste Manag. 32 (2012) 1459 doi: https://doi.org/10.1016/j.wasman.2012.02.011

21. Snellings, R., Mertens, G., Cizer, O., Elsen, J., Early age hydration and pozzolanic reaction in natural zeolite blended cements: Reaction kinetics and products by in situ synchrotron X-ray powder diffraction, Cem. Concr. Res. 40 (2010) 1704. doi: https://doi.org/10.1016/j.cemconres.2010.08.012

22. Caputo, D., Liguori, B., Colella, C., Some advances in understanding the pozzolanic activity of zeolites: The effect of zeolite structure, Cem. Concr. Composites 30 (2008) 455. doi: https://doi.org/10.1016/j.cemconcomp.2007.08.004

23. Poon, C. S., Lam, L., Kou, S. C., Lin, Z. S., A study on the hydration rate of natural zeolite blended cement pastes, Constr. Build. Mater. 13 (2009) 427. doi: https://doi.org/10.1016/S0950-0618(99)00048-3

24. Krolo, P., Krstulović, R., Dabić, P., Bubić, A., Hydration and leaching of the cement-zeolite composite, Ceramics-Silicaty 49 (2004) 213.

25. Perraki, T., Kakali, G., Kontoleon, F., The effect of natural zeolites on the early hydration of Portland cement, Microporous Mesoporous Mater. 61 (2004) 205. doi: https://doi.org/10.1016/S1387-1811(03)00369-X

26. Uzal, B., Lutfullah, T., Mehta, K., High-volume natural pozzolan concrete for structural applications, ACI Mater. J. 104 (2007) 535

27. Barbir, D., Dabić, P., Krolo, P., Evaluation of leaching behavior and immobilization of zinc in cement-based solidified products, Hem. Ind. 66 (2012) 781. doi: https://doi.org/10.2298/HEMIND120228038B

28. Krstulović, R., Krolo, P., Ferić, T., Microcalorimetry in the cement hydration process, Periodica Politechnica 33 (1989) 315.

29. Heikal, M., El-Didamony, H., Morsy, M. S., Limestone-filled pozzolanic cement, Cem. Concr. Res. 30 (2000) 1827. doi: https://doi.org/10.1016/S0008-8846(00)00402-6

30. Tamas, F. D., Csetenyi, L., Tritthart, E., Effect of adsorbent on the leachability of cement bonded electroplating wastes, Cem. Concr. Res. 22 (1992) 399. doi: https://doi.org/10.1016/0008-8846(92)90082-7

31. Giergiczny, Z., Krol, A., Immobilization of heavy metals $(\mathrm{Pb}, \mathrm{Cu}, \mathrm{Cr}, \mathrm{Zn}, \mathrm{Cd}, \mathrm{Mn})$ in the mineral addtions containing concrete composites. J. Hazard. Mater. 160 (2008) 247. doi: https://doi.org/10.1016/j.jhazmat.2008.03.007

32. Perraki, T., Kontori, E., Tsivilis, S., Kakali, G., The effect of zeolite on the properties and hydration of blended cements, Cem. Concr. Composites 32 (2010) 128. doi: https://doi.org/10.1016/j.cemconcomp.2009.10.004 